\title{
Book review of: the red bandana...a life. a choice. a legacy
}

Volume 6 Issue 6 - 2017

\section{Opinion}

Quite a story about a 24 year old man who died 9/11 in the South Tower of the World Trade Center's Islam-caused destruction in 2001-a happy day for Koranaholics everywhere--with Islam's Satanic entropy hating all who do not grovel in the dirt to adore power more than love. Welles Crowther was his name. He wanted to be a firefighter like his father and volunteered for local fire stations until his death. Doing well enough as a business analyst for a promising New York Wall Street firm on the 104th floor of the Trade Center, he planned to quit and join the local fire department. The recently acquired, but uncompleted, official application forms for FDNY were destroyed with him.

The United Trade Center contained 14,154 people that Pearl Harbor morning--2,977 died, thousands still suffer, and two magnificent human built monuments were destroyed. The Fire Department New York lost 343 members and 24 Port Authority members died in rescue efforts. Survivors, struggling to recover, began to remember escaping the massacre. Eight months after it happened, a newspaper article told of those on the 78th floor of the South Tower where a wing of Flight 175 exploded into the building killing many waiting for the elevators: "Chaos and suffering" do not adequately convey what it was like for those still breathing and trying to move.

Who was that masked man? And play the William Tell Overture. "A mysterious man appeared at one point, his mouth and nose covered with a red handkerchief. He was looking for a fire extinguisher" (page 157). Many, who were helped to survive, repeated the description of the young red-masked Lone Ranger who led them to safety, carrying a young black woman and a fire extinguisher which he gave to another man with instructions for safety and encouragement to continue out. Covered by a red bandana, to protect his nose and mouth from the pulverized rubble and crud in the air, he led and directed hundreds to safety. Then, "I'm going back up" (page 126), obviously hoping to direct and lead more out, but remaining oblivious to his own survival.

"It took ten seconds for the tower's 750 million tons of heavy steel and concrete to drop, erased from the skyline, a sudden phantom" (page 130). Thus physical entropy engulfed Welles as he turned it into spiritual synthesis--the ultimate Christian message from his lifetime church, Grace Episcopal in Nyack, and from his alma mater, Boston College.

When Welles' body was found: “To be so close to an escape but to remain inside was not coincidence. Likely, it was a choice. Welles made it. He was helping. He was at work. (page 153)"

All readers will discover what it means to be a "fireman" by "order of service" (page 142) used by Hook and Ladders of New York City:

The last alarm has sounded for our brother.

To Welles has come that last call.

It is the call from which there is no turning away,

\section{Samuel A Nigro M.D}

Retired, Assistant Clinical Professor Psychiatry, Case Western Reserve University School of Medicine, USA

Correspondence: Dr. Samuel A Nigro M.D., Retired,Assistant Clinical Professor Psychiatry, Case Western Reserve University School of Medicine, 2517 Guilford Road, Cleveland Heights, Ohio 44I I8, USA, Tel 216 932-0575, Email sam@docnigro.com

Received:September 24, 2016 | Published: February 06, 2017

\section{The imperative and final order,}

Of the great chief and captain of us all...

In the 141 years since the FDNY founding, Welles was the second person to be posthumously named an honorary member of its ranks.

And I add to my long-standing short list of un-corrupted government employees who can be trusted: the military, the postal service, the police, and, now, "firemen." (Check out The Firefighter's Prayer(s) on the Web.)

Rinaldi gives innumerable vignettes of Welles childhood which teach the importance of virtue and altruistic innocence in childhood, currently now destroyed for many by adult sexualization and violence of the press and media. Since given by his father, the red bandana, cherished and used, was with him for seventeen years: "To wipe away sweat and dirt, or clean up a mess, or keep the hair out of his eyes. Or to polish up a bumper or a gleaming silver bell. The handerchief was a welcome sight, especially during the endless cleaning and polishing that went into the firehouse day" (page 21-22). Kidded by friends, family and co-workers, the red bandana was a religious reminder of the ultimate human purpose to do good and avoid evil. On September 9, 2001, walking with his parents, his mother noticed the red bandana: "Welles, are you still carrying that thing?" (page 92). It was his scapular. Perhaps to be learned, is that something comparable should be given to every child on their seventh birthday, as I touched my St. Christopher medal worn for 70 years.

This book was strange to read--I kept thinking I was at Mass-the Catholic celebration of life, sacrifice, virtue, love, humanity, 
peace, freedom and death without fear. But I got through it. Filled with "parables" and without scribes and Pharisees, the book becomes pure spirit and another example, I believe, of matter creating spirit. The book is transcendent: true, one, good and beautiful. Needless to write, it inspires virtue, fatherhood, motherhood, family love, getting an education, working hard, going to church, and living and dying for humanity. It is a crafted masterpiece. A child raising manual for all parents.

\section{Acknowledgments}

None.

\section{Conflicts of interest}

None.

Funding

None. 